\title{
Experimental Investigation of Air Conditioner using the Desiccant Cooling System in Equatorial Climates
}

\author{
Kamaruddin Abdullah ${ }^{1, *}$, Aep Saepul Uyun ${ }^{1}$, Syukri Muhammad Nur ${ }^{1}$, Alie Bamahry ${ }^{1}$, Rino Imanda ${ }^{1}$, and \\ Teuku Meurah Indra Mahlia ${ }^{2,3}$ \\ ${ }^{1}$ The Graduate School, Renewable Energy Program of Study, Darma Persada University, Jl.Radin Inten II, Pondok Kelapa- \\ East Jakarta, 13450, Indonesia \\ ${ }^{2}$ Department of Mechanical Engineering, Universiti Tenaga Nasional, Jl. Ikram-Uniten, 43000 Kajang, Selangor, Malaysia \\ ${ }^{3}$ School of Systems, Management and Leadership, Faculty of Engineering and Information Technology, University of \\ Technology Sydney, 81 Broadway, Ultimo NSW 2007, Australia
}

\begin{abstract}
Indonesia lies in the tropical climate which requires air conditioning to increase working productivity of the people. Up to now people are still using the compressive cooling system which uses Freon as the refrigerant, which have been known to have a negative environmental impact. Therefore, new cooling system which is environmentally friendly is now needed. Desiccant cooling system manipulates the humidity condition of outside air in such a way so that the final temperature should become at $25{ }^{\circ} \mathrm{C}$ and $\mathrm{RH}$ of $65 \%$. Since it does not require refrigerant, a desiccant cooling has the potential to be developed in a tropical country like Indonesia. In this study an experimental desiccant cooling system has been designed and constructed and tested under laboratory condition. Experimental results have shown that the resulting air temperature was $26.1{ }^{\circ} \mathrm{C}$ with $\mathrm{RH}$ of $55.6 \%$, and average cooling capacity was $0.425 \mathrm{~kW}$. The COP was found to be 0.44 .
\end{abstract}

Key words: Air conditioning, desiccant cooling, desiccant wheel, evaporative cooling, sensible heat exchanger.

\section{Introduction}

Indonesia economic growth rapidly for last two decades, this economic growth subsequently increases the energy demand in the country. The pattern of energy consumption, energy scenario and sustainable energy in the country discussed deeply by Hasan et al. [1,2]. Due to this reason the country trying to develop alternative energy sources for every sector in the country such as geothermal [3], bioenergy [4], biodiesel [5-8] bioethanol [9-11]. The country also actively promotes energy efficiency and sustainable energy program as to counter global warming [12-15]. This research a part of improving human comfort in the tropical climates indirectly also will contribute to energy conservation program in the country.

Indonesia lies on the equator with an average temperature of $30{ }^{\circ} \mathrm{C}$ and $\mathrm{RH}$ of above $80 \%$ [16]. Under this weather condition it is not fit for people to work in the office or stay at home. Therefore, there is an urgent need for air conditioning facilities in order to be able to live in a better condition. There is also need for industry to increase their productivity by creating a better working environment. Heretofore, people have been using the compressive cooling system which Freon as the refrigerant. As we know Freon having a bad impact on ozone depletion has been prohibited its use, according to the Montreal protocol [17]. In this study a desiccant cooling system was selected, due to its environmentally friendly nature. This cooling system does not emit greenhouse gasses since the working principle is on how to manipulate the condition of the air so that a pleasant air condition can be achieved. This can be obtained by first heating the desiccant wheel with solar collector to get rid of moisture from the desiccant. Later within the evaporative component of the desiccant cooling system, the air temperature will be cooled down by the evaporation of cooling water of the evaporative cooling while its relative humidity will increase from the moisture added from the evaporative cooling water [18-21]. For the purpose of this study a laboratory scale desiccant cooling system was designed and

\footnotetext{
*Corresponding author: kamaruddinabd@gmail.com
} 
constructed and later a series of test was conducted to obtain the performance of the system. The current heater of the system used electric power, but later it will be replaced by a solar collector.

\section{Literature study}

Research on the desiccant cooling system is quite new in Indonesia and very rare if any attempt to apply the system in Indonesia. Research by Maalouf [23] indicated that the use of solar energy they were capable to construct adsorption cooling system for application in several city in France. Daou et al. [24] have conducted research to determine the performance of an adsorption cooling machine using silica gel the Pennington cycle. Mavroudaki et al. [25] reported two studies related to the feasibility of adsorption cooling machine using solar energy Pennington cycle in South Europe

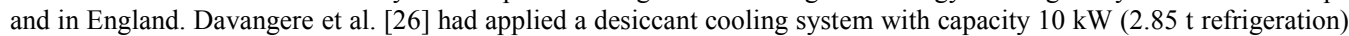
assisted by vapor compression machine. The resulting room temperature $26.7^{\circ} \mathrm{C}$ with humidity ratio of $\mathrm{W}=0.01183 \mathrm{~kg}$ $\mathrm{kg}^{-1}$ dry air for the condition Florida which have outside air of $36^{\circ} \mathrm{C}$. They conducted an analysis using a psychometric chart and the result of their simulation works were applied to four cities in the USA. Bellia et al. [22] had studied several hybrids cooling system using various desiccant wheels and using DesiCalcTM computer program and applied to four cities in Italy. They concluded that the maximum saving in cost was $22 \%$, and for the theater the saving was greater from $23 \%$ to $38 \%$ with electricity saving of up to $55 \%$. Pesaran,et al. [27] had studied experimental dessicant cooling operated in ventilation mode and the rusults were presented in Psychrometric chart. A heat supply was needed in the system to regenerate the desiccant (natural Zeolite) and a low-grade heat at a temperature of about $60.95{ }^{\circ} \mathrm{C}$ was used. Parametric studies are performed to investigate the effects of ambient temperature and relative humidity on the various COP terms and cooling load.

\subsection{Working principle of the desiccant cooling system.}

Figure 1 shows the major component of a desiccant cooling system which comprises of a desiccant wheel (DW) containing natural Zeolite or silicagel, sensible heat exchanger wheel (rotary heat exchanger), an electric heater which can be substituted with hot water supplied from solar collectors, two evaporative coolers (EC1 and EC2). Outside air is introduced through point (1) passing the hot desiccant wheel where the humidity is reduced to the point (2). The air will further pass through the sensible heat exchanger (point 3) where its temperature will be reduced while keeping its $\mathrm{RH}$ constant. From the sensible heat exchanger, the air will be introduced into the evaporative cooling chamber where its temperature will be reduced due to evaporative cooling action while its $\mathrm{RH}$ will be increased (point 4). When entering the room, the temperature and $\mathrm{RH}$ will reach $25{ }^{\circ} \mathrm{C}$ and $65 \%$, respectively, a comfortable condition for air conditioning. The air condition in the desiccant cooling system can also be traced using the Psychometric chart in Figure 2. When the air is leaving the air condition room under condition of point (5) the air will be passed again through the evaporative cooling unit which will reduce its temperature and increase its RH (point 6). After passing through the sensible heat exchanger, its temperature will increase while its RH is kept constant as in point (7). After passing through the evaporative cooler (point 6), the tempeature the air silgthly is decreased while its RH is increased. After passing through the sensible heat exchanger, its temperature will increase while its RH is kept constant as in point (7). After this the air will pass the solar air heater where the air temperature increases again heating the desiccant within the desiccant wheel to make moisture from silica gel evaporated, the air than become as the condition of point (8). After passing the desiccant wheel the air will be exhausted to the environment at a lower temperature (point 9).

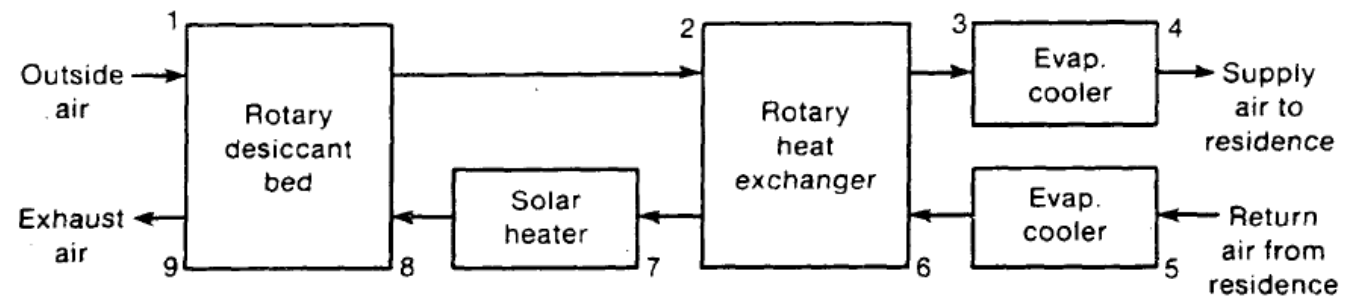

Fig. 1. Main component of desiccant cooling system [27]. 


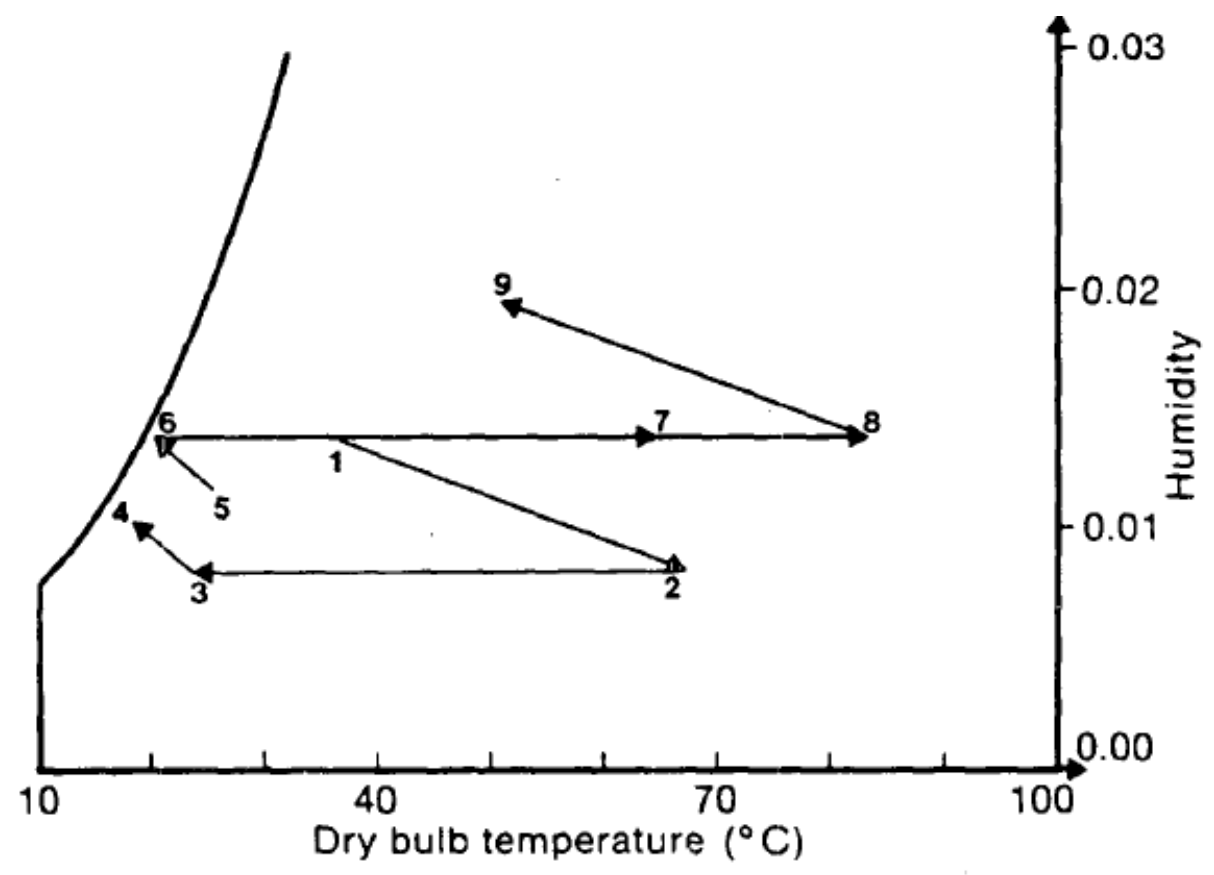

Fig. 2. The condition of the air as represented by a psychometric chart [27].

\section{Experiment setup}

\subsection{The apparatus and instruments}

The apparatus used in the experiment is as shown in Figure 3. It consisted of a desiccant wheel (2) equipped with a motor to turn it, a blower with the heater (3) to function as a solar collector, a sensible heat exchanger (4) and an evaporative cooling system (5). In addition, there was a blower located in front of the desiccant wheel to draw outside air into the four $50 \mathrm{~mm}$ ID PVC piping and length of $0.46 \mathrm{~m}$. In addition there was one blower located in front of desiccant wheel (1). During the test all components of the system were started simultaneously and the outside air was introduced through the duct inlet and passing through the desiccant wheel. The condition of the air will change as it passed through each component of the system as explained in the section 2.1. on working principle of the desiccant cooling system. For measuring each data an Automatic data acquisition system shown in Figure 4 was used. Several DHT 11 sensors for measuring both temperature and RH were placed according to the number point in Figure 3 and then all connected to the Arduino UNO microcontroller, shown in Figure 4 and then to the computer. For measuring air flow rate an electronic anemometer was used while for measuring water flow rate in the evaporative cooling system an electronic sensor was used. For measuring the RPM of the desiccant wheel and sensible heat exchanger a Laser \& Touch Tachometer DT-2236B a tachometer was used. 


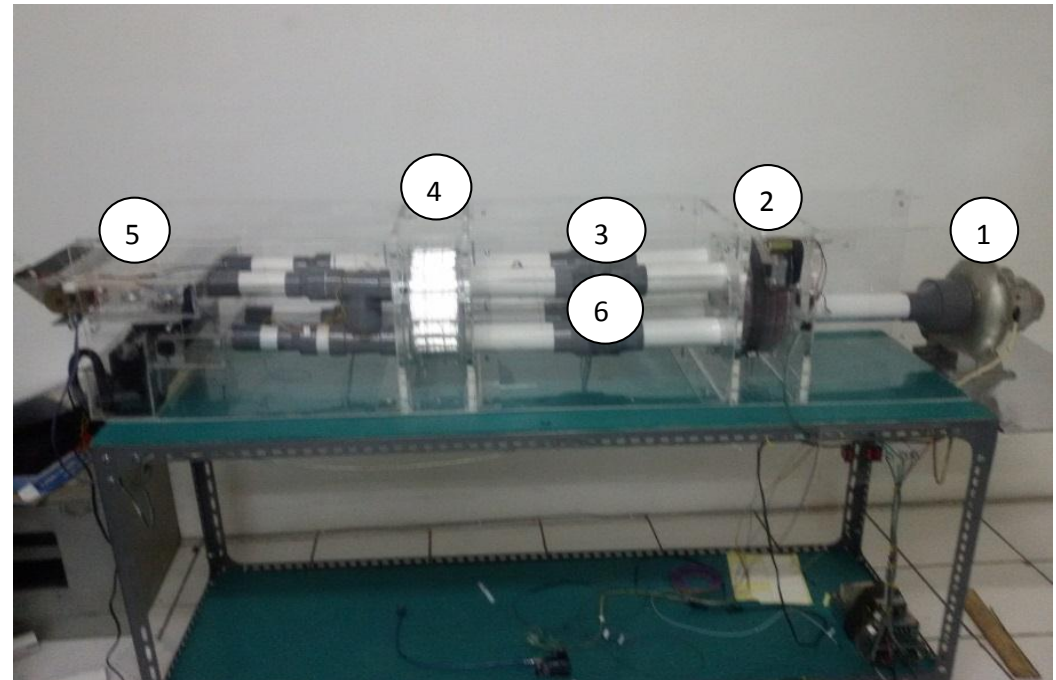

Fig. 3. Experimental apparatus.

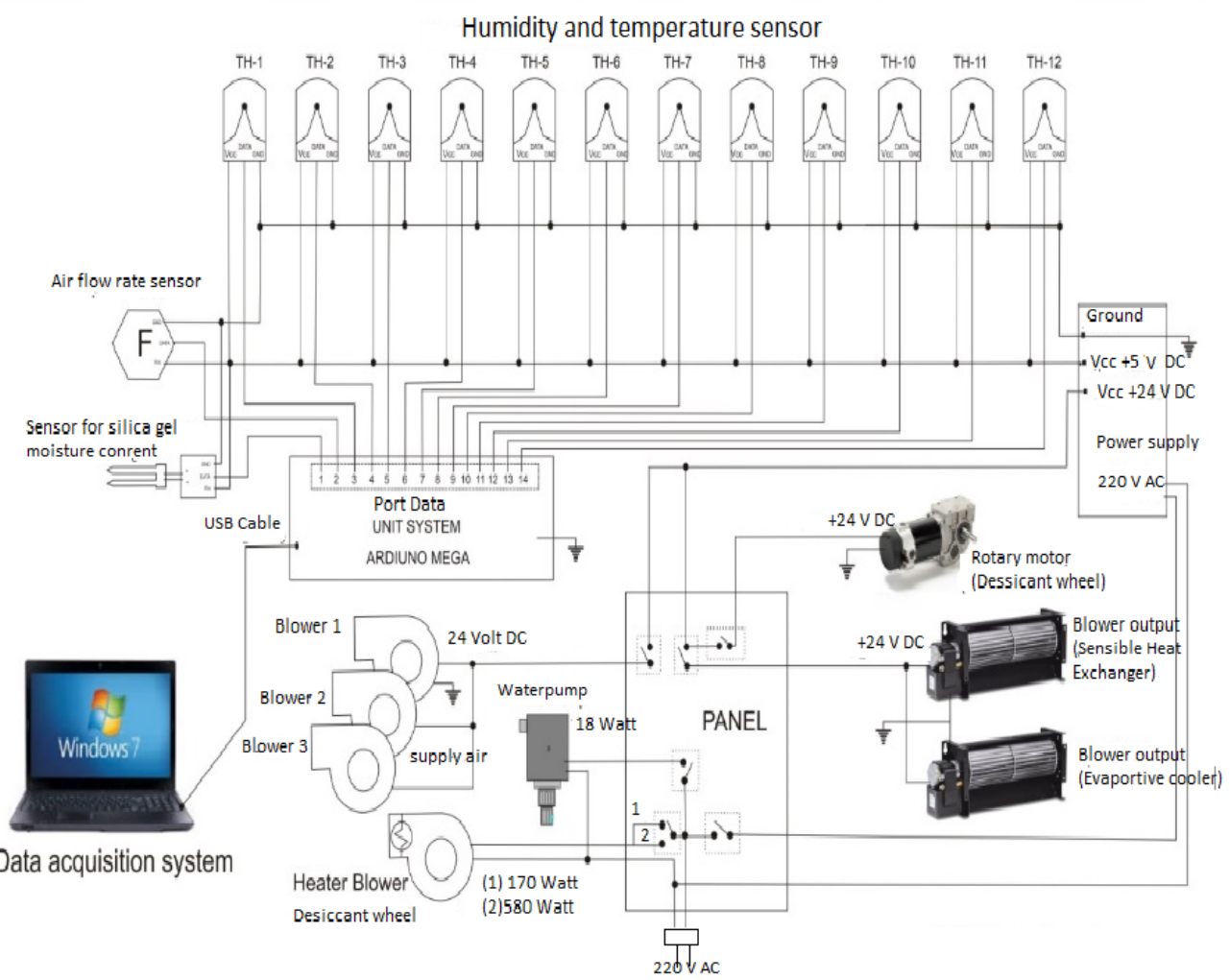

Fig. 4. Automatic data acquisition system. 


\subsection{Experimental procedure}

First, it was necessary to fill the desiccant wheel with adequate amount of silica gel. The silica gel, then was spread and glued on both sides of aluminum plates arranged in such a way to give an ample way of the air passing through the desiccant wheel and the silica gel. The desiccant wheel was put on a steel bar axis rotated together with the sensible heat exchanger by means of a $24 \mathrm{~V}$ DC electrical motor. Several aluminum plates were placed in the sensible heat exchanger to cool the air ling the desiccant wheel and heating the air coming from the evaporative cooler. The evaporative cooler consisted of porous pad above which spray nozzles were placed to spray cool water to the pad. There were two evaporative coolers provided one before entering the air-conditioned space and after the air return from the air-conditioned space. At the outlet before the desiccant wheel a $580 \mathrm{~W}$ electric heater was placed to provide heat to evaporate moisture from the desiccant wheel. Four blowers were provided one in front of the desiccant wheel to switch the air and discharged to the surrounding environment, one after the desiccant wheel in front of the sensible heat exchanger and one each at the evaporative cooler inlet. After putting all the sensors at the specified location as given in Figure 3, the desiccant cooling system was operated and data were taken automatically by means of a laptop computer.

\section{Results and discussions}

Typical experimental results indicated that the temperature of air leaving the sensible heat exchanger was at $33.5{ }^{\circ} \mathrm{C}$ while the air temperature leaving the evaporative cooling system was at $26.1{ }^{\circ} \mathrm{C}$, while the $\mathrm{RH}$ was at $55.6 \%$. As the air flow rate passing through the evaporative cooling system was at $5 \mathrm{~m} \mathrm{~s}^{-1}$ then the calculated cooling power of the system was $0.425 \mathrm{~kW}$ (see Table 1). When the heat input from the heater was used the COP was found to be 0.44 which was lower than the recorded data by Davangere et al. [27] which was 0.66. Table 1, shows the results of experimental run for the temperature difference between the sensible heat exchanger exit and the evaporative cooling exits from this data together with air flow rate the cooling capacity could be calculated as shown in the 5th column of Table 1, and in Figure 6. While, Figure 5 shows the variation in outlet temperature leaving the sensible heat exchanger and that leaving the evaporative cooler. It was found that the heating power was inadequate to heat the desiccant wheel so that the air temperatures were still low while the air RH was low. The evaporation of cooling water in evaporative cooler was inadequate to increase air RH so that the cooling effect was not adequate to cool the coming air from the sensible heat exchanger. Therefore, the heating capacity of the electric heater should be increased while the spray water flow rate with the evaporative cooler should be reduced.

Table 1. Experimental results from temperature differences between sensible heat exchanger exit, evaporative cooling exit, cooling capacity and air RH at the evaporative cooler outlet.

\begin{tabular}{|c|c|c|c|c|c|}
\hline Run & $\begin{array}{c}\mathrm{T} 3\left({ }^{\circ} \mathrm{C}\right) \text { (Evaporative } \\
\text { cooling exit) }\end{array}$ & $\begin{array}{c}\mathrm{T} 4\left({ }^{\circ} \mathrm{C}\right) \\
\text { (sensible heat exit) }\end{array}$ & $\begin{array}{l}\text { Air flow rate } \\
\qquad\left(\mathrm{m} \mathrm{s}^{-1}\right)\end{array}$ & $\begin{array}{c}\text { Cooling capacity } \\
\text { kW }\end{array}$ & $\begin{array}{l}\text { RH }(\%) \text { after } \\
\text { evap cooling }\end{array}$ \\
\hline 1 & 24.6 & 33.15 & 5 & 0.336 & 58.9 \\
\hline 2 & 25.2 & 33.5 & & 0.326 & 53.3 \\
\hline 3 & 25.2 & 33.8 & & 0.338 & 52.3 \\
\hline 4 & 24.9 & 33.1 & & 0.322 & 52 \\
\hline 4 & 25.7 & 35.2 & & 0.373 & 55.4 \\
\hline 5 & 26.3 & 39 & & 0.499 & 57 \\
\hline 6 & 26.8 & 39 & & 0.479 & 51.9 \\
\hline 7 & 27.3 & 40.2 & & 0.507 & 51.9 \\
\hline 8 & 27.5 & 41 & & 0.530 & 62.2 \\
\hline 9 & 27.2 & 41 & & 0.542 & 61 \\
\hline Ave. & 26.07 & 36.9 & & 0.425 & 55.59 \\
\hline
\end{tabular}




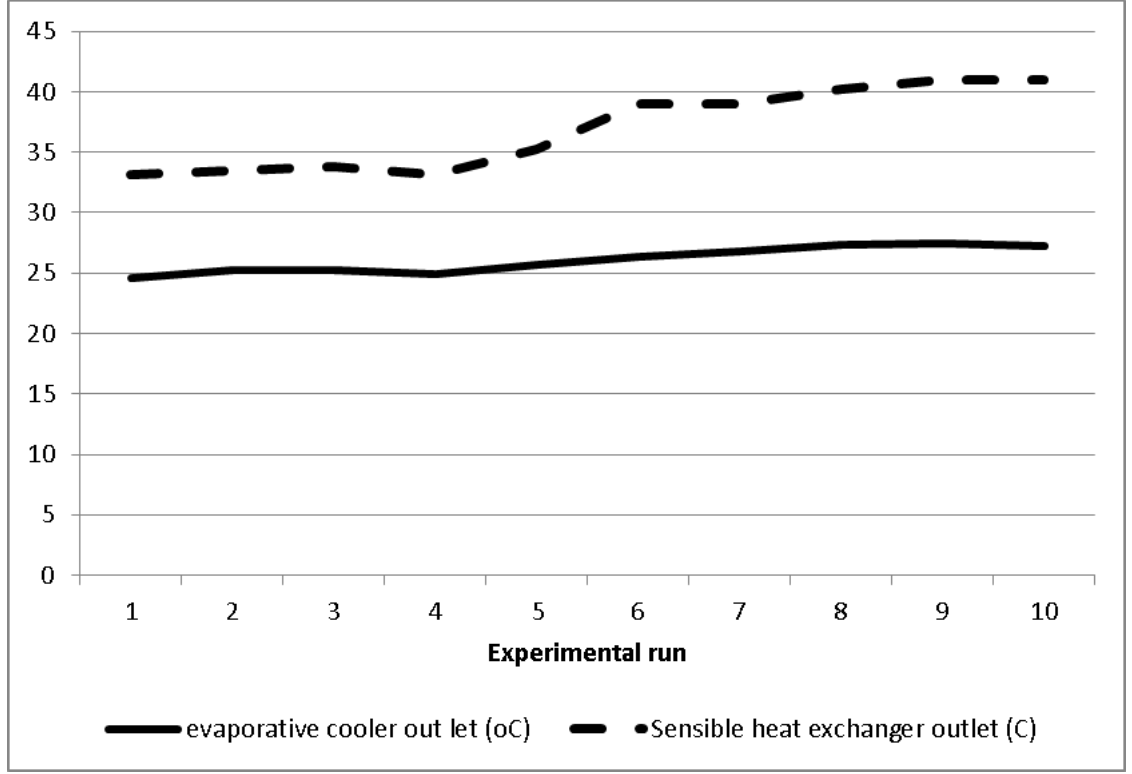

Fig. 5. Air temperature difference between sensible heat exchanger outlet and that of evaporative cooler outlet.

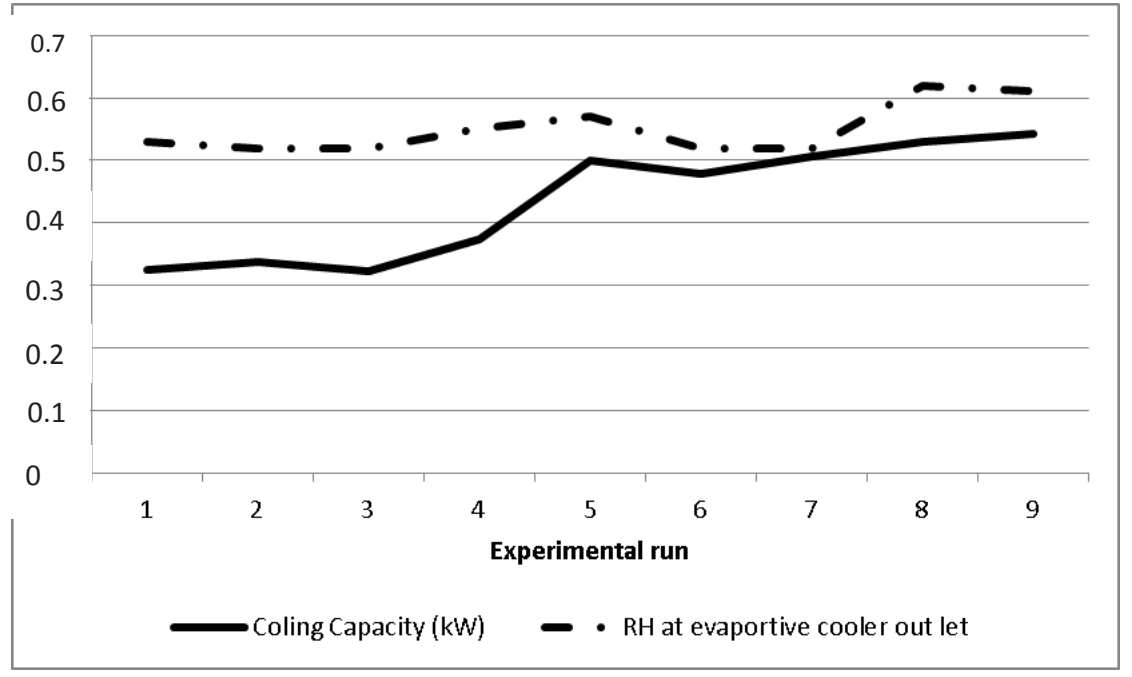

Fig. 6. Cooling capacity of the experimental desiccant cooling system and the air RH at the evaporative cooler outlet.

\section{Conclusions}

From experimental results, it was found that the average cooling capacity of the system achieved was $0.425 \mathrm{~kW}$.The final temperature and $\mathrm{RH}$ leaving the air duct was $26.1^{\circ} \mathrm{C}$ and $55.59 \%$, respectively. The COP of the system was found to be 0.44 .It was recommended that the evaporative cooling water flow rate should be reduced to allow good contact with the coming air while heating power should be increased so that it could create standard comfort where a temperature of $25^{\circ} \mathrm{C}$ and $\mathrm{RH}$ of $65 \%$ can be created.

The authors wish to thank the Directorate General of Research and Technology and Higher Education for providing us research grant through contract No.104/K3/KM/2015, February 23, 2015. 


\section{REFERENCES}

1. M.H. Hasan, T.M.I. Mahlia, H. Nur. Renew. Sust. Energ. Rev., 16(4):2316-2328 (2012).

https://www.sciencedirect.com/science/article/pii/S1364032111005995

2. M.H. Hasan, W.K. Muzammil, T.M.I. Mahlia, A. Jannifar, I. Hasanuddin. Renew. Sust. Energ. Rev., 16(5):3206-3219. https://www.sciencedirect.com/science/article/pii/S1364032112000871

3. Nasruddin, M.I. Alhamid, Y. Daud, A. Surachman, A. Sugiyono, H.B. Aditya, T.M.I. Mahlia. Renew. Sust. Energ. Rev., 53:733-740 (2016). https://www.sciencedirect.com/science/article/pii/S1364032115010023

4. T.M.I. Mahlia, M.Z. Abdulmuin, T.M.I. Alamsyah, D. Mukhlishien. Energy Convers. Manag., 42(18):2109-2118 (2001). https://www.sciencedirect.com/science/article/pii/S0196890400001667

5. F. Kusumo, A.S. Silitonga, H.H. Masjuki, H.C. Ong, J. Siswantoro, T.M.I. Mahlia. Energy, 134:24-34 (2017). https://www.sciencedirect.com/science/article/pii/S0360544217309921

6. F. Kusumo, A.S. Silitonga, H.C. Ong, H.H. Masjuki, T.M.I. Mahlia. Energy Sources, Part A: Recovery, Utilization and Environmental Effects, 39(13):1339-1346 (2017). http://www.tandfonline.com/doi/abs/10.1080/15567036.2017.1328003

7. M.H. Jayed, H.H. Masjuki, M.A. Kalam, T.M.I. Mahlia, M. Husnawan, A.M. Liaquat. Renew. Sust. Energ. Rev., 15(1):220-235 (2011). https://www.sciencedirect.com/science/article/pii/S1364032110002893

8. A.S. Silitonga, A.E. Atabani, T.M.I. Mahlia, H.H. Masjuki, I.A. Badruddin, S. Mekhilef. Renew. Sust. Energ. Rev., 15(8):3733-3756 (2011). https://www.sciencedirect.com/science/article/pii/S1364032111002462

9. H.B. Aditiya, W.T. Chong, T.M.I. Mahlia, A.H. Sebayang, M.A. Berawi, H. Nur. Waste Management, 47:46-61 (2016). https://www.ncbi.nlm.nih.gov/pubmed/26253329

10. H.B. Aditiya, T.M.I. Mahlia, W.T. Chong, H. Nur, A.H. Sebayang. Renew. Sust. Energ. Rev., 66:631-653 (2016). https://www.sciencedirect.com/science/article/pii/S1364032116303434

11. N. Hossain, J.H. Zaini, T.M.I. Mahlia. International Journal of Technology, 8(1):5-18 (2017). http://www.ijtech.eng.ui.ac.id/old/index.php/journal/article/view/3948

12. L. Aditya, T.M.I. Mahlia, B. Rismanchi, H.M. Ng, M.H. Hasan, H.S.C. Metselaar, et al. Renew. Sust. Energ. Rev., 73:1352-1365 (2017). https://www.sciencedirect.com/science/article/pii/S1364032117302484

13. M. Amin, N. Putra, E.A. Kosasih, E. Prawiro, R.A. Luanto, T.M.I. Mahlia. Appl. Therm. Eng., 112:273-280 (2017). https://www.sciencedirect.com/science/article/pii/S1359431116323845

14. A.E. Atabani, A.S. Silitonga, T.M.I. Mahlia, Renew. Sust. Energ. Rev., 16(5):3547-3558 (2012). https://www.researchgate.net/publication/236853970_Cost_benefit_analysis_and_environmental_impact_of f uel economy standards for passenger cars in Indonesia

15. A.S. Silitonga, A.E. Atabani, T.M.I. Mahlia, A.H. Sebayang. Renew. Sust. Energ. Rev., 15(9):5212-5217 (2011). https://www.sciencedirect.com/science/article/pii/S1364032111001407

16. T. Uno, S. Hokoi, E.S. Nastiti. Journal of Asian Architecture and Building Engineering, 2(2):15-21 (2003). https://www.jstage.jst.go.jp/article/jaabe/2/2/2 2 b15/ pdf

17. M.W. Roberts. Review of European, Comparative and International Environmental Law, 26(3): 220-230 (2017). http://onlinelibrary.wiley.com/doi/10.1111/reel.12225/full

18. S. Khosravi, T.M.I. Mahlia, Y.H. Yau. Feasibility study of hybrid wheel desiccant dehumidification cooling systems in Malaysia. ASHRAE Transactions, 2010 Winter Conference, 116:392-397. (Orlando, 2010). https://www.thefreelibrary.com/Feasibility+study+of+hybrid+wheel+desiccant+dehumidification+cooling...a0227975407

19. S. Khosravi, Y.H. Yau, T.M.I. Mahlia, M.H. Saidi, A new approach to exergy analyses of a hybrid desiccant cooling system compares to a vapor compression system. International Conference on Mechanical and Aerospace Engineering (ICMAE) (Venice, Italy, 2011). Applied Mechanics and Materials, 110-116:2163-2169 (2012). https://www.scientific.net/AMM.110-116.2163

20. M.A. Fazilati, A.A. Alemrajabi, A. Sedaghat. Heat and Mass Transfer, 54(3):903-913 (2018). https://link.springer.com/article/10.1007/s00231-017-2191-4

21. F. Zhang, Y. Yin, X. Zhang. Building and Environment, 117:218-229 (2017). https://www.sciencedirect.com/science/article/pii/S0360132317301130

22. L. Bellia, P. Mazzei, F. Minichiello, and D. Palma, "Air conditioning systems with desiccant wheel foritalian climates," International Journal on Architectural Science, vol. 1, no. 4, pp. 193-213, 2000.

23. C. Maalouf, E. Wurtz, F. Allard. Evaluation of the cooling potential of a desiccant evaporative cooling system using the SimSPARK environment. UTAP, University of Reims, Campus du Moulin de la Housse. [online] from http://citeseerx.ist.psu.edu/viewdoc/download?doi=10.1.1.576.6438\&rep=rep1\&type=pdf (2006). [Accessed on 18 February 2018].

24. K. Daou, R.Z. Wang, Z.Z. Xia. Renew. Sust. Energ. Rev., 10(2):55-77 (2006). https://www.sciencedirect.com/science/article/pii/S1364032104001200

25. P. Mavroudaki, C.B. Beggs, P.A. Sleigh, S.P. Halliday. Appl. Therm. Eng. 22(10):1129-1140 (2002). https://www.sciencedirect.com/science/article/pii/S1359431102000340

26. B.S. Davanagere, S.A. Sherif, D.Y. Goswami. International Journal of Energy Research, 23(1):7-21 (1999). http://onlinelibrary.wiley.com/doi/10.1002/(SICI)1099-114X(199901)23:1\%3C7::AID-ER439\%3E3.0.CO;2U/abstract 
27. A.A. Pesaran, T.R. Penney, A.W. Czanderna. Desiccant cooling: State-of-the art asessement. Washington: National Renewable Energy Laboratory A, Division of Midwest Research Institute, operated for the US Department of Energy Under Contract No DE-AC02-83CH10093, (1992).

https://www.osti.gov/biblio/6925169 